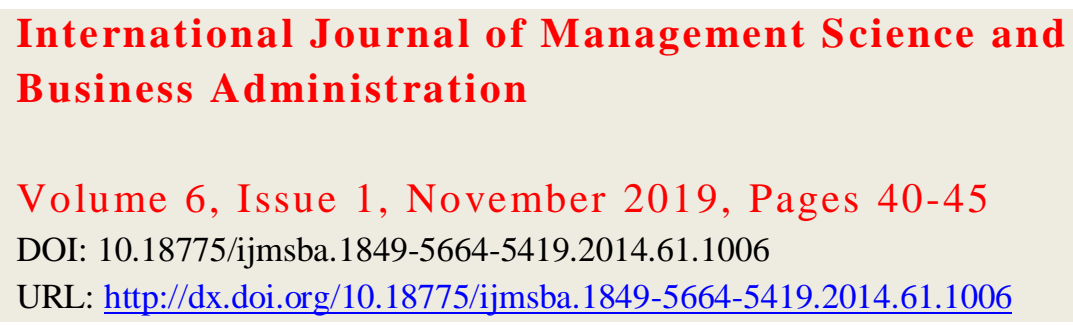

\title{
Unique Features of Asset Securitization of Europe and Japan
}

\author{
Akhmedov Akbarali Sultonmurodovich \\ Independent Researcher of Tashkent State Economic University, Tashkent, Uzbekistan
}

\begin{abstract}
Asset securitization practices are almost non-existent in the activities of financial institutions of Uzbekistan. The article explores theoretical and practical approaches to asset securitization. It analyzes asset securitization of Europe and Japan using comparative evaluation, scientific abstraction and systematic review methods. The problem areas were studied and conclusions made on them. Several solutions have been proposed to introduce asset securitization processes in Uzbekistan.
\end{abstract}

Keywords: Assets, Securitization, Securities, Emissions, Risk, mortgage loan, Auto loan

\section{Introduction}

The securitization of commercial banks' assets is one of the most promising and actively developing mechanisms of the financial market. Today it plays an essential role among modern financing tools. In particular, the effective use of these financial derivatives is especially crucial, given the high demand for financial resources by commercial banks and the limited availability of free funds. Limited resources for attracting investments into the economy of our country, in turn, make it necessary for commercial banks to choose the most effective investment activities. At this moment, the absence of securitization practice in commercial banks of the country necessitates the creation of the following preconditions, such as: Formation of liquid debt obligations, which serve as the basis for the securities circulation; establishment and provision of uninterrupted operation of the number of specialized financial institutions; creation of an active stock market, etc.

By the Decree of the President of the Republic of Uzbekistan on February 7, 2017, No. P-4947 "On the strategy for the further development of the Republic of Uzbekistan" the development of lending activities of commercial banks, increase by 1.2 times in their lending to economies and small businesses to meet the demand for financial resources has been identified. This, in turn, necessitates the development of scientific proposals and recommendations for the implementation of up-to-date methods of asset securitization of commercial banks in the context of liberalization of the banking system of Uzbekistan. The following determines the relevance of the topic of this article.

\section{Literature Review}

Conceptual basis of the process of asset securitization of commercial banks, its functions, forms and principles has been explored in the work of foreign economists and experts such as L. Schwartz, H. Peris, E. Hartwood, J. Gill, A. Andreas, J. Bart, He Tong Li, X. Ber and P. Rose.

Studies on the empirical evaluation and modeling of sequenced securitization agreements have been explored in the scientific work of several CIS scientists and economists; namely, N. Aleksandrova, A. Rachkevich, and M. Sukhanov. Some aspects of the practice of asset securitization have been studied by some local economists as well. Scientists like I. Butikov, D. Gozibekov, N. Karimov, M. Tashkhodjaev, and M. Muminova have explored some different aspects of asset securitization. Economist PS Rousseau interpreted the concept of "securitization" as a mechanism for increasing asset turnover. According to him, asset securitization is the transformation of non-liquid assets into liquid assets that can be freely traded in the financial market. Hans Peter Ber, a Swedish scientist and professor of the University of Zurich states that "Securitization of assets is the most advanced method of financing. Within its scope, exclusion of differentiated assets from the credit institution or other enterprise, presence of legal independence by transferring assets to a specially 
created legal entity, refinancing of the assets in the international funds market by issuing securities have been realized".

The economist Stephen Schwartz, in his work on the alchemy of asset securitization, views asset securitization as "the ability of securitization organizers to attract resources in the investment market by offsetting all or part of the receivables within the lowest costs". Also, one of the local economists, M.Muminova, in her research work, offers the use of soft loans based on government programs as an asset in the asset securitization. It should be noted that no independent research has been carried out on the securitization of bank assets in our country so far. Economists of our country have studied only some aspects of securitization of commercial banks assets, and thus, there are some limitations within developed scientific and theoretical frameworks. The lack of scientifically grounded proposals and recommendations on the possibility of introducing experience of foreign countries into the practice of Uzbekistan didn't enable the existing problems to be solved.

\section{Research Methodology}

Theoretical foundation of the study has been developed based on the investigation of foreign and local economists' approaches and views on the topic. Practical aspects of the article is based on the analysis of the experience of foreign countries and evaluating the feasibility of using practices of foreign banks in the asset securitization practices of Uzbekistan. Comparative evaluation, scientific abstraction and systematic review methods have been used in the research.

\section{Analysis and Results}

The formation of "asset securitization" as an economic term began with the "street rumors" by Anna Monroe (Wall Street Journal (1977)). Agreement called "Bank of America issue" was first made with Solomon Brothers Bank. Lewis Ranieri, the director of the Mortgage Department at Solomon Brothers Bank, suggested the concept of "securitization" in his interview with Wall Street Journal to explain the process of issuing mortgage-backed securities on the basis of "the warranty of the right for inquiry".

In the mid-1980s, asset securitization practice was started to be widely used in several developed countries, including the US, UK, France, the Netherlands, Germany, Spain, Italy, Austria, Japan, and Canada. At the same time, large international banks - lenders, issuers, guarantors, and investors - began actively participating in the asset securitization activities. One of such bank is the Dutch bank ABN AMRO. Subsequently, securitization was also carried out on the basis of other assets. For example, in March 1985, the American credit company Credit Suisse First Boston invested in securitization of future lease payments for Sperry Lease Corporatio. The United States concluded the first venture deal of $\$ 192$ million. At the same time, Western Financial Savings, USA, started issuing securities based on auto loans. This implies the use of new types of securities in securitization practice. Asset-Backed Securities (ABS) - "Securities with Assets" - has become widely known and has become one of the most commonly used securitization tools of the future.

\section{Securitization Practices in European Countries}

Along with the expansion of securitization valuables in the US, this practice has also developed in Europe. In turn, the development of global trade with securities has led to fierce competition between the United States and developed European countries within the realm of the conflict of interests.

The European securities market differs from the US securities market by asset diversification and direct public sector participation (Andrew Davidson, 2004). With the development of the stock market in Europe, the practice of securitization also became popular. One of the main reasons for the introduction of securitization in European countries is that this mechanism allows commercial banks to optimize their finances under strict limits and competition. In particular, securitization has allowed commercial banks to meet minimum capital requirements (by transferring credit risks to companies with investments). Also, the next reason for the development of securitization in Europe is the widespread use of bonds covered by commercial banks in the region as a means of attracting additional resources for financing.

It is noteworthy that the European debt securities market differs considerably in comparison to the US market. These differences are also related to the practice of securitization. An analysis of the European securitization market reveals that this practice is commonly based on Covered bonds and Assets Securities (ABS). Today Covered bonds play a crucial role in the European financial market. In particular, Germany, France, Spain, and Denmark widely use the model of refinancing through bond issuance under securitization. The German, French, Spanish, and Danish mortgage markets 
represent more than $70 \%$ of the European bond market, indicating that this debt instrument has a strong presence in Europe today.

The issuance of European bonds has taken the securitization to the higher quality level, which in turn has led to the issuance of Collateralized Loan Obligations (CLO). Collateralized Debt Obligation (CDO) is now actively used in Western Europe and the United States. These operations are also carried out with the purpose of transferring investment features to the type of securities that are in demand. Collateralized Debt Obligation (CDO) is a favorable corporate debt obligation to expand investor opportunities. This mechanism allows restructuring the flow of payments generated by existing debt (Petrovichev Yu.A, 2019).

In 2018, UK Provided Housing Mortgages (RMBS) reached to 6.1 billion euros. Growth in 2018 in the European Credit Guarantee (CLO) reached to 3.5 billion euros and the amount of "Auto loans" provided by Germany reached to 1.6 billion euros. The total amount of financial instruments was: UK Secured Housing Mortgage (RMBS) - 20.1 billion euros, 39 percent of the total; European Credit Guarantee Facility (CLO) - 13.7 billion euros, 22 percent of the total; "Secured car loans" of Germany - 11.4 billion euros, 10 percent of the total (Figure 3).

As you can see from the picture, nowadays, the securitization market in Europe is well developed and has managed to form its structure. Securitization practices are designed to improve the functioning of the European banking system, which currently includes a large number of different securities transactions. For all countries, government regulation is essential. This is because the regulators have used the mechanism of securitization to mitigate the negative impact of the global financial and economic crisis. At the same time, the main instrument of the state is the development of regulatory frameworks to regulate and redistribute cash flows in public finance.

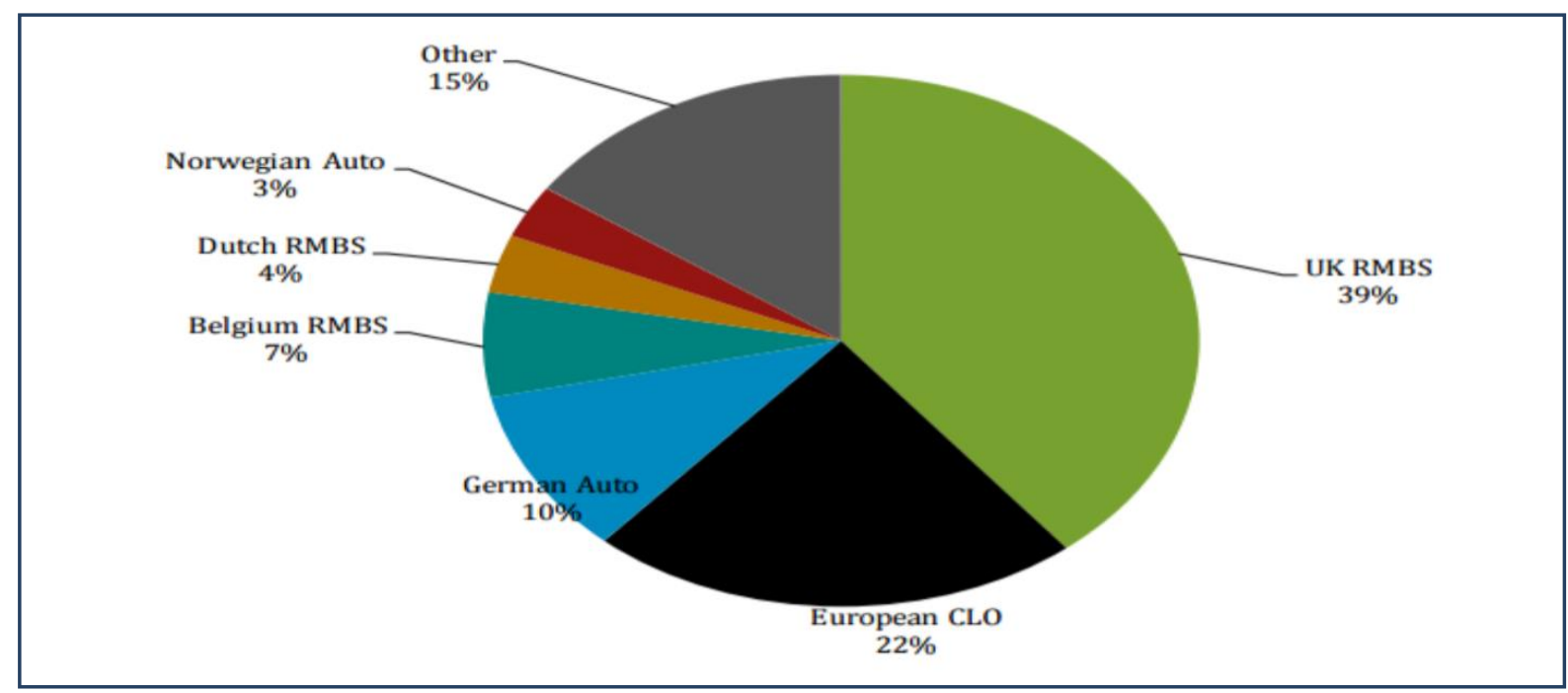

Figure 1. Structure of European securitization agreements in 2018, in percent (AFME Securitisation Data Report, 2018)

The experience of foreign countries shows that the mechanism of securitization can also be used for the development of the real sector of the economy, reducing the cost of financing in the banking system and increasing the number of sources and investors. Generally, securitized assets are primarily loans. Here, securitized assets can also include prospectively paid income. Usually, securitization is a way to convert loans and other receivables into securities (World Bank, 1993). The use of the securitization mechanism opens up ample opportunities for emerging financial markets, thereby, ensures economic stability and mitigates the impact of risks in the financial sector. It is noteworthy that currently industrialized countries actively use financial instruments (securities) issued on the basis of securitization in their risk management practice. Securitization in the traditional ("classic") sense means refinancing the securities market by transferring financial assets on the balance of a commercial bank (initiator, originator) to a third party (Specialized Vehicle, SPV) (H. Beer; Yu. Alekseev, Ivanov, Walters Clover, 2007). The following factors may affect the market for securitized assets:

- the economic situation at the country or economic situation of the sector;

- current financial market situation; 
- effectiveness of fiscal policy;

- regulatory and legal requirements;

- evaluation methodology of asset securitization by the rating agencies.

The cases, as mentioned above, enables us to form the proper picture of trends in market stabilization of the securitized assets. The impact of securitization on the financial system may vary depending on the different structures or implementation quality of monetary policy in developed countries. Also, the degree of influence varies with the development of securitization practices in the country. Securitization increases the efficiency of the financial system. Its active use may affect monetary policy of the country (IFC, 2016).

\section{Japanese Experience of Asset Securitization}

In Japan, securitization practices are commonly based on financial derivatives such as Secured Housing (RMBS) and Assets Securities (ABS). In this regard, these financial instruments are clearly classified as top class assets. RMBS and ABS account for almost half of the total emissions. As for RMBS, Japan Housing Finance Agency (JHF) - the Japanese Mortgage Financing Agency is the largest issuer of financial derivative at current time. The issuance of ABS is mainly carried out by issuers based on auto loans and consumer loans. If we look at the current state of issuance of securitizationbased financial derivatives, we can see some progress. So, at the end of Q1 2018, Japan's issuance of securitized financial derivatives amounted to 19.3 trillion yen. This is 895 billion dollars more than in the same period of 2017 , also $4.9 \%$ higher (Figure 4). As shown in the picture, the number of Japanese emissions under securitization has been steadily increasing since September 2014. The volume of securities issued on the basis of securitization also shows a tendency to grow from 2014 to 2018 .

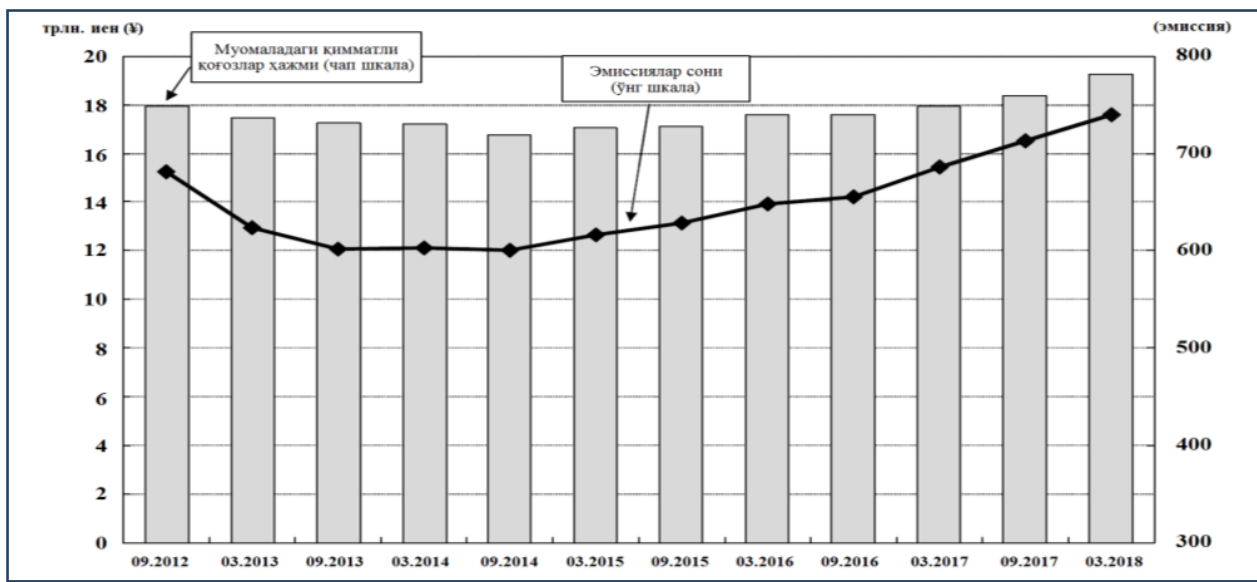

Figure 2: Number of issued securities and volume of securities issued in the framework of securitization in Japan, trillion yen (JSDA, 2018)

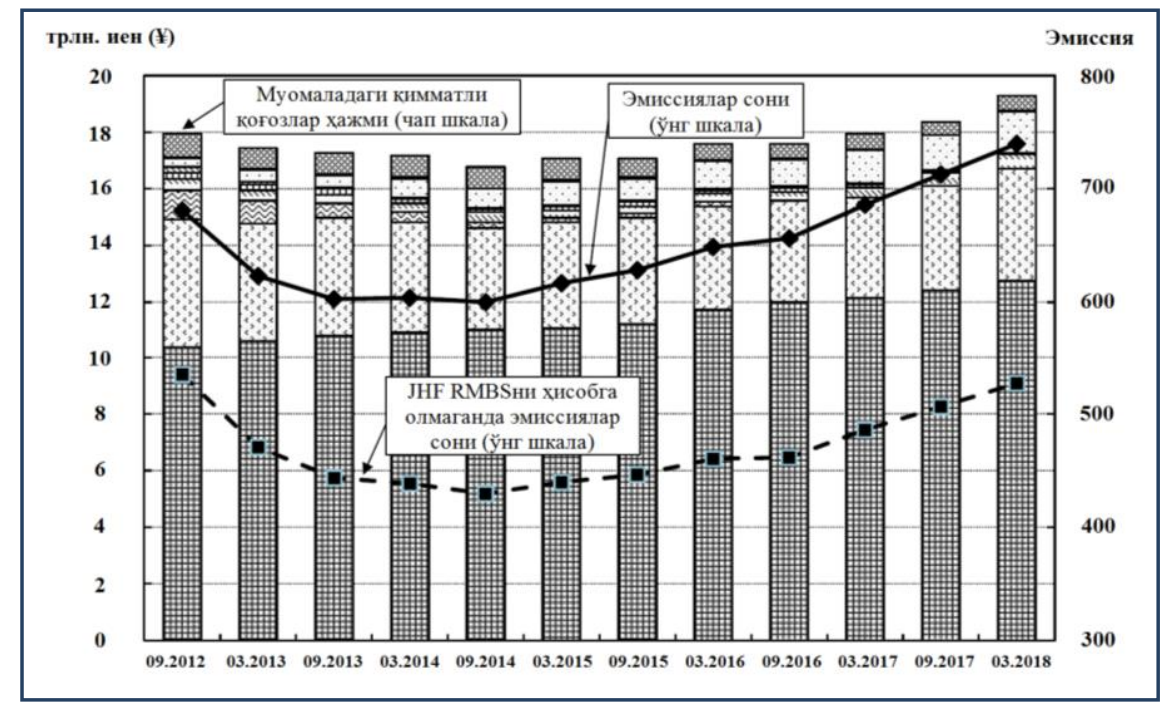


Accounts Receivable / Commercial Bills

$\Rightarrow$ Issued residential mortgage securities excluding

JHF

曲 Residential mortgage securities issued by JHF

图 Commercial mortgage securities

Other types of securities
Trade Loans

$\mathbb{V}$ Consumer loans

II Leasing Loans

Secured debt obligations

Figure 3: Volume of securities issued in the framework of securitization in Japan, trillion yen (JSDA, 2018)

Structural analysis of securities issuance based on securitization shows that RMBS (excluding JHF and JHF) accounts for a significant share in total volume of outstanding securities, including RMBS in Q1 2018. This type of securities accounted for $86.6 \%$ of the total volume of issued securities, which amounted to 16.7 trillion yen (Figure 3 ).

Analysis of the data in Fig 2.8 shows that the majority of RMBS securities in circulation under securitization account for RMBS shares have been issued by JHF. In the first quarter of 2018, the volume of RMBS emitted by the JHF was 12.7 trillion yen. This is $66.1 \%$ of the total RMBS volume. The volume of securitized securities on trade credits also showed a high growth trend and reached to 1.45 trillion yen. The share of this derivative in total securities is 7.5\% (JSDA, 2018).

\section{Conclusions and Suggestions}

The study of European and Japanese experience will enable us to integrate securitization methods and tools to Uzbekistan. It should be noted that currently commercial banks of the republic do not use securitization practice. The main reasons why this practice is not yet widely used are due to a number of factors:

- underdevelopment of the securities market in our country and the inability of this market to perform the functions of distribution and redistribution of financial resources;

- the poor performance of institutional investors in the financial market and their absence in the securities market;

- Lack of regulatory legal acts on asset securitization and the absence of a mechanism to stimulate this activity;

- Low opportunity of placement of securities issued on the basis of asset securitization in domestic and foreign financial markets;

- Underdevelopment of the financial market infrastructure, in particular, the lack of investment intermediary institutions, etc.

In general, the prospect of introducing and developing securitization in our country should begin with an improvement in the legislative framework. Securitization of assets in our country requires the following tasks:

- implementation of measures to develop a system of institutional investors;

- the introduction of a market mechanism for the formation of credit histories of commercial banks in Uzbekistan;

- publish statistics on early loans;

- Encouraging domestic and foreign investors to invest in new financial instruments.

It should be noted that the financial market of Uzbekistan is not integrated into the world financial markets. The share of foreign investors in the domestic financial markets is due to the underdevelopment of the local financial markets and the lack of capital controls.

\section{References}

- $\quad$ Agarwal, S., \& Mohtadi, H. (2004). Financial markets and the financing choice of firms: Evidence from developing countries. Global Finance Journal, 15(1), 57-70.

- $\quad$ Aleksandrova, N. V. (2007). Poniatie i vidy sekiuritizatsii aktivov. Concept and types of asset securitization].//Finansy i kredit, (5), 36-42.

- $\quad$ Babaeva, G. Y., Nazarova, V. I., \& Murodova, S. N. (2018). Procedure for opening and maintaining bank accounts in the Republic of Uzbekistan. World Scientific News, 91, 130-137. 
- $\quad$ Barth, J., Li, T., Malaiyandi, S., McCarthy, D., Phumiwasana, T., \& Yago, G. (2005). capital access index: Securitization in financing economic activities. Capital Studies, Milken Institute, US.

- Braun, B., \& Hübner, M. (2018). Fiscal fault, financial fix? Capital Markets Union and the quest for macroeconomic stabilization in the euro area. Competition \& Change, 22(2), 117-138.

- Davidson, A., Sanders, A., Wolff, L. L., \& Ching, A. (2004). Securitization: Structuring and investment analysis (Vol. 285). John Wiley \& Sons.

- $\quad$ Ekimova, k., Nikeriasova, v., Hvostenko, o., \& Ivanova, y. (2017). Mortgage lending as a financial management tool. Revista ESPACIOS, 38(49).

- Frank, F. J. (2000). Bond Markets, analysis and strategies.

- Gill, A. J. Why Does Securitization Exist?.

- Jan, M. Q., \& Faruqi, S. H. (1995). Khewra Trap: An unusual ultrapotassic rock in the Salt Range of Pakistan. Journal of Nepal Geological Society, 11, 237-252.

- Karimov, N. G., \& Tashkhojayev, M. M. (2016). Prospects for the development of securitization of banking assets in Uzbekistan. Austrian Journal of Humanities and Social Sciences, (9-10). Crossref

- Khalikov, U. (2017). Role of Stock Exchanges in Economic Development of Uzbekistan. International Business Research, 10(1), 172-180.

- Kotov V.A. (2007) Organization of the securities market, 20-23

- Lee A.A. (2002) International experience in the development of municipal securities and its application in the conditions of Uzbekistan, 19-20

- Maeda, T., \& Pardieck, A. M. (2018). ADR in Japan's Financial Markets \& the Rule of Law. NEULJ, 10, 400.

- Mahnovski, S., Akramov, K., Karasik, T. W., \& Karasik, T. (2007). Economic dimensions of security in Central Asia (Vol. 417). Rand Corporation.

- Mahnovski, S., Akramov, K., Karasik, T. W., \& Karasik, T. (2007). Economic dimensions of security in Central Asia (Vol. 417). Rand Corporation.

- $\quad$ Rachkevich, A. Y., \& Alekseeva, I. A. (2008). Securitization: characteristic features and definition. Money and credit/A. Rachkevich, I. Alekseeva, (8), 22-31.

- Schwarcz, S. L. (1994). The Alchemy of Asset Securitization, 1 Stanford Journal of Law. Business \& Finance, 133.

- Schwarez L. (2004). The Aichemy of Asset Securitization: Standford Journal of Lo, Business \& Finance (2004). 130 - 136.;

- Spechler, M. C. (2008). The economies of Central Asia: A survey. Comparative Economic Studies, 50(1), 30-52.

- Sukhanov M.S., Bogdanov A.E. (2012) All you need to know about asset securitization by banks / Sukhanov MS, // Accounting and banks, 1-8.

- Usoskin, V. M. (1994). Modern Commercial Bank: management and operations. Vazar Ferro, Moscow, 314.

- Гордійчук, I. С. (2015). Секьюритизация как инновационный метод финансувания проектов государственно-частного партнерства в Украине. Экономический вестник университета. Сборник научных трудов ученых и аспирантов, (26-1). 